\title{
The Development of China's FDI Laws and Policies after WTO Accession
}

Chunlai Chen

\section{Introduction}

Policies and reforms relating to foreign direct investment (FDI) have been among the most fundamental aspects of China's economic reforms. During the past three decades, China's change of attitude from restricting to passively attracting and then to actively selecting inward FDI has been fully reflected by the evolution of its FDI policies, laws and regulations. Given China's global ranking as an FDI destination and the vast quantity of FDI inflows into its domestic economy (accumulative FDI inflows of about US\$1000 billion during the past three decades), this reform process relating to FDI appears to have been extremely successful.

After China's accession to the World Trade Organisation (WTO) in 2001, China further liberalised its FDI regime in conformity with WTO rules and requirements. In terms of trade in goods, China progressively lowered its tariffs and phased out non-tariff measures, with its simple average tariff rate dropping from 42.9 per cent in 1992 to 15.3 per cent at the beginning of 2002, and further to 9.8 per cent in 2010. China has also made substantial commitments in services, opening up more sectors to international trade than any other WTO member. Furthermore, China agreed to fully implement the General Agreement on TradeRelated Aspects of Intellectual Property Rights (TRIPS) to provide intellectual property rights protection and enforcement, while also committing to comprehensively implement the Agreement on Trade-Related Investment Measures (TRIMs) after entering into the WTO, and to reduce foreign investment barriers and to liberalise its FDI regime.

China's accession to the WTO has had a positive impact on its FDI policy regime, particularly with regard to national treatment and transparency. Meanwhile, it has also provided the impetus for China to improve its competition policies, industrial policies and intellectual property rights protection and enforcement. The development of China's FDI laws and policies since WTO accession has been marked by the rapid development of a systematic regulatory framework to facilitate and regulate FDI. Two characteristics are prominent. First, emphasis has been placed on the creation and development of a more consistent and systematic regulatory framework. Second, more efforts have been made to create and amend the legislation in conformity with international rules and requirements for FDI.

This chapter aims to provide an overview of the development of China's FDI laws and policies since its WTO accession. The next section discusses the main changes in the three laws governing the legal entities of FDI firms - namely, the Equity Joint Venture Law, the 
Contractual Joint Venture Law and the Wholly Foreign-Owned Enterprise Law. The main features of the Provisions on Cross-Border Mergers and Acquisitions (M\&As) and the Anti-Monopoly Law are then presented, followed by a discussion of the development and adjustments of industrial policies for FDI. The chapter then analyses the unification of the tax system for domestic and FDI firms, before drawing some conclusions regarding future liberalisation prospects and challenges.

\section{Amendments of laws governing the legal entities of FDI firms}

According to China's laws, foreign investors may choose three main legal entities to invest in China-namely, equity joint ventures, contractual joint ventures, and wholly foreign-owned enterprises. In the 1990s, some new forms of FDI were gradually allowed, such as limited companies with foreign investment and foreign-invested holding companies.

The Equity Joint Venture Law was issued in 1979, and was China's first law permitting and governing the establishment and operations of foreign economic entities in its territory. In 1986, to accommodate the needs of foreign investors and to attract more FDI inflows, the Chinese Government issued the Wholly Foreign-Owned Enterprise Law. In 1988, the Contractual Joint Venture Law was finally adopted.

The Equity Joint Venture Law was amended in 1990 to abolish the stipulation that the chairman of the board of an equity joint venture should be appointed by Chinese investors and to add the provision of protection from nationalisation.

In 1994, China issued the Company Law. The Company Law did not do away altogether with the three legal entities of FDI firms. Instead, it attempted to reclassify them under one of the two classes of companies: the limited-liability company and the company limited by shares. Based on the Company Law, foreign joint ventures and wholly foreign-owned enterprises are all limited-liability companies.

To meet the requirements of entering the WTO, the Chinese Government amended the Wholly Foreign-Owned Enterprise Law and the Contractual Joint Venture Law in 2000, and the Equity Joint Venture Law in 2001 substantially. ${ }^{1}$ The amendments removed earlier restrictions in the areas of foreign exchange balance requirements, raw materials and equipment sourcing, mandatory export requirements, and reporting of business plans. These legislative amendments represent the first major step on the part of the Chinese Government to honour its commitments under pending WTO membership. The key amendments are listed below. 


\section{Abolition of the foreign exchange balance requirement}

Previously, FDI firms were required to balance their own foreign exchange income and expenses. Pursuant to the earlier requirements, where an FDI firm desired to make payments or remittances in foreign currency outside China, these had to be made from the company's own foreign exchange funds. The foreign exchange balancing requirement has now been deleted from the law. Foreign direct investment firms may now purchase foreign currency from commercial banks under the new legal regime, subject to the satisfaction of the relevant foreign exchange control rules.

\section{Equal access to domestic and overseas suppliers}

Foreign direct investment firms were required under previous laws to give priority to domestic suppliers when sourcing their raw materials and equipment. The new amendments permit free sourcing of raw materials, fuel, components, and so on from either China's domestic market or overseas, without priority requirements favouring domestic suppliers.

\section{Removal of the mandatory export requirement}

Previously, the Wholly Foreign-Owned Enterprise Law required FDI firms to export at least 70 per cent of their production, except where special exemptions were granted, such as for advanced technology contributions. Mandatory export requirements were also imposed on joint ventures, in order to support the earlier foreign exchange balance requirement. Under the newly adopted amendments, mandatory export requirements have been removed. China will encourage the use of advanced technology and the export of products, but each FDI firm shall be free to allocate sales of its products to either China's domestic or its export market.

\section{Abolition of business plan filing}

Previously, FDI firms were required to file their production and business plan with the relevant government authority. The newly adopted amendments repeal this requirement, as the current focus for government control is on macroeconomic matters, rather than the operations of individual enterprises.

In 2005, China fundamentally amended the Company Law. The new Company Law, ${ }^{2}$ which came into effect on 1 January 2006, is a significant reform of the old Company Law. The old Company Law had been criticised for various deficiencies, especially in terms of corporate governance. The new Company Law simplifies company establishment requirements and statutorily expands the rights of shareholders in China's companies.

The provisions of the new Company Law apply to FDI firms to the extent that they do not conflict with the statutes governing these investment vehicles-namely, equity joint ventures, cooperative joint ventures and wholly foreign-owned enterprises. Each of these forms of FDI firms is organised in China as a limited-liability company. The statutes and associated regulations provide for specific and unique provisions concerning each of these three legal entities of FDI firms in China. Where the unique provisions do not apply, the provisions of the new Company Law apply. 


\section{The issue of provisions on cross-border mergers and acquisitions and the Anti-Monopoly Law}

During the past two decades, global FDI flows have been dominated by cross-border M\&As, particularly in the services sector. Cross-border M\&As in China have, however, been very limited due to the tight restrictions imposed by the Chinese Government. Since 2003, the Chinese Government has permitted foreign investment through cross-border M\&As in a limited fashion. To fulfil its WTO commitments, and to further liberalise the FDI regime and attract more FDI, China issued the Interim Provisions on Mergers and Acquisitions of Domestic Enterprises by Foreign Investors ${ }^{3}$ in 2003 (also referred to hereinafter as 'the Provisions'). This is the first comprehensive set of regulations on cross-border M\&As in China.

After a three-year trial period of the Interim Provisions on M\&As, on 8 August 2006, six Chinese ministries jointly issued the Provisions on Mergers and Acquisitions of Domestic Enterprises by Foreign Investors, ${ }^{4}$ which took effect on 8 September 2006. The Provisions establish new rules for foreign investors acquiring interests in China's domestic companies.

The Provisions apply to any M\&As by foreign investors, including foreign companies, foreign-invested investment companies registered in China, and foreign-invested enterprises (collectively referred to as 'foreign investors') of domestically registered companies, including limited-liability companies, companies limited by shares, state-owned enterprises, private companies and foreign-invested enterprises (collectively referred to as 'domestic companies').

The Provisions define that a merger or acquisition of a domestic enterprise by foreign investors could mean either an equity acquisition or an asset acquisition. An equity acquisition is defined as the acquisition by foreign investors of equity interest in a domestic company or the subscription by foreign investors of new equity in a domestic company, resulting in the conversion of such a domestic company to an FDI firm. An asset acquisition is defined as including both: 1) the establishment of an FDI firm by foreign investors with the purpose of using the FDI firm to acquire and operate assets purchased from domestic companies; and 2) the direct acquisition of assets from domestic companies by foreign investors who then use those assets for establishing an FDI firm.

The Provisions represent a further opening towards cross-border M\&As in line with standard international practice in that they allow for the first time the acquisition of equity interests held by shareholders of a Chinese domestic company by payment of equity interests held by shareholders of an overseas company or new shares issued by an overseas company. The Provisions increase corporate transparency by requiring parties to a crossborder acquisition to disclose whether or not they are affiliated with each other and, if they are under the common control of the same entity, to provide additional information regarding the purpose of the acquisition and whether the appraisal results conform to fair market value. The Provisions make specific and detailed provision for the use of a specialpurpose vehicle (SPV) overseas by Chinese domestic firms making acquisitions in Chinaan important addition in view of the generally unrecorded but widespread practice of 
'round-tripping' by Chinese companies seeking to benefit from incentives offered to foreign investors. The Provisions also establish interim anti-monopoly review procedures to protect market competitiveness and stability until the anti-monopoly law is promulgated.

On the other hand, the Provisions add a new screening requirement on cross-border M\&A transactions in which the foreign investor obtains controlling rights of a domestic enterprise if the acquisition: 1) involves a major industry; 2) has or might have an impact on national economic security; or 3) might result in the transfer of famous trademarks or traditional Chinese brands. The lack of definition of terms, including 'major industry', 'impact' on 'national economic security', 'famous' trademarks and 'traditional' Chinese brands, appears to render the new screening requirement less than wholly transparent. The creation of a new layer of screening is in addition to the examination and approval process based on the Catalogues for Guidance of Foreign Investment Industries. It does not appear consistent with the repeatedly expressed intention of the Chinese authorities to streamline FDI approval procedures.

Although there are differences of opinion regarding whether the Provisions actually encourage or restrict foreign investment, there are positive indications that the legal environment for inward cross-border M\&As in China is becoming more flexible (for example, use of shares as consideration) and settled (for example, more detailed approval procedures have been introduced).

After more than 10 years of debate and drafting, China enacted its first ever AntiMonopoly Law, ${ }^{5}$ in 2007, commencing operation on 1 August 2008. Article 1 of this law states that it was enacted for the purpose of preventing and prohibiting monopolistic activities; protecting fair market competition; promoting efficiency of economic operation; protecting the legitimate rights and interests of consumers and social public interests; and promoting the healthy development of a socialist market economy. The law sets out various rules regarding the regulation or prohibition of monopoly agreements, including resale price maintenance, price fixing, and anti-competitive supply and market practices. Various agreements may be exempted from the prohibition of monopoly agreements, including those that relate to technology development, cost reduction and resources preservation. Undoubtedly, the Anti-Monopoly Law will have significant implications on FDI in China, especially for FDI through cross-border M\&As.

The Anti-Monopoly Law itself does not distinguish between foreign and domestic businesses. Until July 2009, however, foreign investors were also subject to pre-merger notification and competition review under the Provisions on M\&As. In order to ensure that the Provisions on M\&As agree with the Anti-Monopoly Law and the Provisions of the State Council on Thresholds for Declaration of Concentrations of Undertakings, the Chinese Government made some revisions to the Provisions on M\&As and the new Provisions on Mergers and Acquisitions of Domestic Enterprises by Foreign Investors, ${ }^{6}$ to take effect in July 2009. The new Provisions on M\&As conform to the pre-merger notification and review provisions in the Anti-Monopoly Law, so that foreign buyers would be subject to only one competition notification and review requirement, under the Anti-Monopoly Law. 
According to the Anti-Monopoly Law, if market concentration reaches the threshold of declaration, a declaration must be lodged in advance with the Anti-Monopoly Authority under the State Council. Cross-border M\&As are regarded as one method of increasing concentration, and should certainly be regulated. The new Provisions on M\&As add one article to regulate the same standard and requirement as the Anti-Monopoly Law in order to maintain consistency across different laws and regulations. Meanwhile, a few linguistic changes have been made in order to avoid controversy and misunderstanding. The modification in the new Provisions on M\&As ultimately ensures the general terms' accurate use in different laws and regulations.

\section{Adjustments of industrial policies for FDI}

China has comprehensive industrial polices to guide FDI into targeted industries in accordance with its economic and industrial development strategy. In 1995, China issued the Interim Provisions on Guiding Foreign Investment and the Catalogue for the Guidance of Foreign Investment Industries (hereinafter referred to as the Catalogue). This was the first time China used laws and regulations to guide FDI. The interim provisions were formulated in order to provide guidance for FDI towards sectors that suit China's national economic and social development plan, and protect the lawful rights and interests of foreign investors in accordance with relevant state laws governing FDI and the requirements of state industrial policy. As a general industrial policy, the Catalogue is a longstanding tool of the Chinese authorities to reflect their decisions and approach towards FDI in various industries at different stages of Chinese economic development. Foreign investors shall first consult with the most updated catalogue to confirm the entry possibility and mode of investment vehicle in the industries in which they intend to invest.

To suit the development of FDI and fulfil China's commitments to the WTO in trade and investment liberalisation, in 2002, China issued the Provisions on Guiding the Orientation of Foreign Investment. ${ }^{7}$ The provisions classify FDI into 'encouraged', 'permitted', 'restricted' and 'prohibited' categories. Foreign direct investment in encouraged industries is normally eligible for various incentives and investors are also permitted to establish wholly foreignowned enterprises, equity joint ventures or cooperative joint ventures. In the event that any industries are not listed in the Catalogue, unless otherwise forbidden by other applicable laws and regulations, FDI is generally permitted and the investment may take vehicles of wholly foreign-owned enterprises, equity joint ventures or cooperative joint ventures with no restriction on Chinese or foreign partners being the majority shareholder. Foreign direct investment in restricted industries is subject to strict governmental examination and approval case by case, and the investment vehicle is possibly limited to equity joint ventures or cooperative joint ventures under which Chinese partners shall hold majority interests in some cases. Foreign direct investment in prohibited industries by any foreign investors is not allowed by any means.

According to the provisions, China encourages both a greater geographic dispersion of FDI inflows within China and more FDI inflows into targeted economic sectors and industries, such as agriculture, resource exploitation, infrastructure, and environmentally friendly, 
export-oriented and high-technology industries. To accommodate the implementation of the provisions, China amended the Catalogue for the Guidance of Foreign Investment Industries in $2002^{8}$ and $2004 .^{9}$

In addition to the national industrial catalogue on guiding FDI, China issued and implemented a series of regional and sectoral industrial catalogues to guide FDI. For example, as part of the Western region development strategy, China issued the Catalogue of Priority Industries for Foreign Investment in the Central-West Region in 2000, which was subsequently amended in 2004 and 2008. ${ }^{10}$ To encourage FDI in high-tech industries, to accelerate the pace of introducing advanced technologies from abroad, to strengthen abilities of internal assimilation and independent innovation, and to further improve the quality and level of FDI, China issued the Catalogue of Encouraged Hi-Tech Products for Foreign Investment in 2003, ${ }^{11}$ which was further amended in 2006. ${ }^{12}$

In 2007, China's National Development and Reform Commission and Ministry of Commerce jointly revised and promulgated the Catalogue for the Guidance of Foreign Investment Industries (amended in 2007), ${ }^{13}$ which replaced its 2004 version and took effect on 1 December 2007.

Compared with its 2004 version, the 2007 Catalogue has not only increased the total number of entries, it has also dramatically expanded the number of 'encouraged' entries. The changes to the Catalogue reflect China's continued effort to attract FDI in accordance with its economic, regional and industrial development strategies. Under the 2007 Catalogue, FDI in traditional manufacturing sectors and export-oriented projects will no longer be encouraged; instead, FDI in high technology, new materials production, high-end equipment, modern agriculture and high-end services, such as modern logistics, has been newly encouraged. Projects associated with heavy pollution or high resources consumption, and exploration of important non-renewable mineral resources, will be forbidden. Some environmentally friendly and energy-saving projects will, however, be welcome. In order to balance regional development, FDI in the central, western and north-eastern regions will also be encouraged. For national economic and 'spiritual' security, some strategic and sensitive industries, such as Internet-based services, are forbidden for FDI.

In April 2010, the Chinese State Council released new regulations on foreign investment (State Council 2010). According to the new regulations, China will improve good business conditions, welcome foreign investment in high-tech industries, service sectors, energy saving and environmental protection, but FDI into polluting and energy-intensive projects or industries running at overcapacity is strictly prohibited. China will continue to support Chinese A-share-listed companies in further introducing strategic investors from home and abroad, and standardise foreign companies' investment in domestic securities and crossborder M\&A transactions. Qualified foreign-funded companies are allowed to go public and issue corporate bonds or medium-term bills in China. Multinationals are encouraged to set up regional headquarters, research and development (R\&D) centres, procurement hubs, financial management and other functional offices in China. Foreign direct investment firms are also encouraged to increase their investment in China's central and western regions, particularly in environmentally friendly and labour-intensive companies ('China unveils 
new rules for foreign investment', 14 April 2010, People's Daily Online, <http://english. peopledaily.com.cn/90001/90778/90861/6949654.html>). The new regulations set out the general guidelines for revising the Catalogue in 2011.

To implement the new regulations, in April 2011, the Legislation Department of the State Council issued the Notice for Public Consultation on the Catalogue for the Guidance of Foreign Investment Industries (Amendment Draft for Consultation), ${ }^{14}$ which is amended jointly by the State Development and Reform Commission and the Ministry of Commerce and will replace the 2007 Catalogue in June-July 2011. Compared with the 2007 Catalogue, now encouraging FDI in strategic new industries and modern services is the most important change.

To support the development of strategic new industries, the new Catalogue adds a number of industries to the encouraged category, including research, development and manufacturing of aero, airspace and environmental friendly materials; manufacturing of key components of new-energy automobiles; research, development and manufacturing of Internet system equipment, software and chips; and construction and operation of vehicle battery recharging stations. In contrast, the manufacturing of whole automobiles is dropped from the encouraged category.

To promote the development of the services sector, the new 2011 Catalogue adds lease and business services, venture investment enterprises, intellectual property services and professional training into the encouraged category, while no longer restricting medical care and health institutions. Foreign direct investment in the construction and operation of villas is, however, prohibited.

These changes demonstrate that China is serious about upgrading its industrial structure through utilising foreign capital in order to achieve sound and healthy economic development. The new Catalogue is expected not only to increase FDI inflows into China but also to improve the industrial and sectoral structure, regional distribution, and the quality of FDI inflows.

\section{Unification of the tax system for domestic and FDI firms}

From the early 1980s to 2007, China extensively but selectively used tax incentives to guide FDI into its designated regions, economic sectors and industries (Wang 1997). China's tax incentive policies for FDI firms have had two key features. First, the tax incentives offered in the special economic zones (SEZs) and economic and technological development zones (ETDZs) located in the open cities were much more favourable than in other open regions. Second, the tax incentives were more favourable for technologically advanced and export-oriented FDI firms. The extensive tax incentives offered to FDI firms not only distorted global capital markets, causing potential diversion of global FDI flows, but also distorted domestic capital markets, creating incentives for round-tripping FDI, and at the same time created unfair competition between domestic firms and FDI firms. 
In 2007 China issued the Enterprise Income Tax Law, ${ }^{15}$ unifying the tax rates for foreign and domestic enterprises. The new tax rate for both domestic and foreign enterprises is 25 per cent. The law took effect on 1 January 2008. The new law has unified the two existing tax codes - one for domestic firms, the other for FDI firms - into one and represents a fundamental change in China's tax policy. Many of the tax incentives and tax holidays that existed in the old code for foreign investors have been changed or eliminated.

The new corporate income tax law and the unification of the tax rate will certainly and substantially reduce the incentive for FDI round-tripping. The impacts of the new tax law on domestic and FDI firms are, however, unclear.

Although the current nominal income tax rate is set at 33 per cent, the actual average income tax burden on China's domestic firms is 25 per cent ('Parliament adopts corporate income tax', Xinhua News Agency, 16 March 2007, <http://news.xinhuanet.com/ english/2007-03/16/content_5854950.htm $>$ ). So, the new tax law, on average, will not reduce the actual tax burden of domestic firms.

The current actual income tax burden on FDI firms is 15 per cent ('Parliament adopts corporate income tax', Xinhua News Agency, 16 March 2007, <http://news.xinhuanet. com/english/2007-03/16/content_5854950.htm >). On average, the new income tax law will increase the tax burden of FDI firms by 10 percentage points. The new tax law is likely to have some negative impact on FDI firms, especially in the short term on small-scale, labourintensive, quick-profit-earning enterprises from developing economies.

Despite the potential negative impact on FDI firms, the unified corporate income tax is likely to have a very limited effect on foreign investment in China, and especially on large multinational enterprises (MNEs), for the following reasons.

First, the average corporate income tax rate for the world's 159 countries and regions that levy corporate income tax is 28.6 per cent, and the average corporate income tax rate for China's 18 neighbouring countries and regions is 26.7 per cent ('Parliament adopts corporate income tax', Xinhua News Agency, 16 March 2007, <http://news.xinhuanet.com/ english/2007-03/16/content_5854950.htm >). China's proposed unified tax rate of 25 per cent therefore remains quite competitive, so the change is unlikely to have a major effect on foreign investment.

Second, numerous surveys of international investors have shown that tax incentives are not the most influential factor for MNEs in selecting investment locations. Foreign investors are of course interested in tax rates, but more important are such factors as the broad investment climate, including the domestic market; the cost and availability of labour; basic infrastructure; and economic and political stability.

Third, China's overall investment environment is quite competitive, with relatively efficient public services, good infrastructure, a large and fast-growing domestic market, abundant and well-educated human resources, low labour costs, and macroeconomic and political stability, making China one of the most attractive locations for FDI. According to the 2005 Foreign Direct Investment Confidence Index (A.T. Kearney 2007), in 2005 China was the most attractive FDI location in the world. China has maintained its lead in the index for the fourth consecutive year. ${ }^{16}$ Once again, China is the top FDI location for first- 
time investors, with more than half ( 55 per cent) of investors expected to make first-time investments there in the next three years. One in five FDI dollars for first-time investments will be committed to the Chinese market. China has successfully overcome the perceived risk associated with first-time market entry, which is typically the biggest barrier to generating new FDI.

Fourth, the new tax law still has preferential stipulations. According to the tax law, China will continue to offer tax incentives to investment in projects concerning environmental protection, agricultural development, water conservation, energy saving, production safety, high-technology development and public welfare undertakings. High-technology enterprises can still enjoy a 15 per cent income tax rate, and small and medium-sized enterprises with slim profits are required to pay income tax at only 20 per cent. Certain tax breaks will also be granted to enterprises in SEZs and less-developed western areas of the country.

Fifth, the new tax law also provides a five-year transitional period to offset the impact on foreign companies. The income tax rate will be gradually increased to 25 per cent during this period, and old foreign enterprises can still enjoy tax breaks within a regulated time limit as before.

Therefore, the new tax law will bring China's tax laws more in line with international standards, which satisfies a WTO commitment to equal treatment for domestic and overseas investors. The change in the tax law not only proves that the Chinese Government is determined to continue its reform and opening-up policies in order to improve investment conditions, but will also help to create a more consistent tax climate for the operations of FDI firms.

On 18 October 2010, the State Council issued the Notice on Unification of City Maintenance and Construction Tax and Education Surcharge for Domestic Enterprises, Foreign Invested Enterprises, and Foreign Individuals. ${ }^{17}$ Foreign direct investment firms and foreign individuals were exempt from the city maintenance and construction tax and education surcharge; such taxes apply only to domestic enterprises and Chinese nationals. Starting from 1 December 2010, China began levying the city maintenance and construction tax as well as the education surcharge on FDI firms and foreign individuals, symbolising the end of 'super national treatment' offered to FDI firms and marking the beginning of a fully unified national tax system for domestic and foreign companies ('China ends foreign firms' "super-national treatment"', People's Daily Online, 1 December 2010, <http://english. peopledaily.com.cn/90001/90778/90861/7217484.html>). China's move to unify the tax system is consistent with relevant WTO provisions and shows that the country is gradually moving towards common international rules. 


\section{Conclusions}

Although China has achieved substantial progress in its FDI policy reform within a relatively short period, comparing China's current FDI policy with the WTO's investmentrelated principles, China's current FDI policy can be further improved, particularly in respect to transparency, national treatment and the protection of intellectual property rights.

With respect to the principle of transparency, China maintains a complex application process for FDI approval, which needs to be simplified and made more transparent through further policy reform.

In terms of national treatment, on the one hand, since the initial offer in the early 1980s of tax incentives to FDI firms, China has extensively but selectively used tax incentives as 'economic levers' to guide FDI into its designated regions, economic sectors and industries. Recent changes to the tax regime for FDI firms mark the beginning of a fully unified national tax system for domestic and foreign companies. This is a step in the right direction towards bringing China's tax laws more in line with international standards and creating a more consistent tax climate for the operations of FDI firms.

On the other hand, to protect some industries and domestic firms, the Chinese Government has introduced regulations to prohibit or restrict FDI participation in some sectors and industries considered to be strategic, sensitive or threatening to national economic and spiritual security. Therefore, foreign investors are not treated equally in accessing and doing business in certain areas in China. The application of national treatment will not only level the playing field between foreign and domestic firms, but will also provide equal incentives and opportunities for various types of FDI and different groups of foreign investors.

Protection of intellectual property rights has long been an issue in China. The weak legal framework and particularly the weak enforcement for intellectual property rights protection in China will not only deter the inflows of FDI with high technology, but will also have a negative impact on foreign investors' decisions to bring technology into China. This could be one of the main reasons for the low level of FDI inflows from industrialised countries into China. Although there has been some improvement, it is still very important for China to further improve the legal framework and strengthen the enforcement for intellectual property rights protection if it wants to attract high-technology FDI inflows from the world's industrialised countries.

China's overall investment environment remains attractive, with relatively efficient public services, good infrastructure, abundant and well-educated human resources, low labour costs, fast economic growth, a huge and growing domestic market, and macroeconomic and political stability. These factors continue to make China one of the most attractive locations for FDI worldwide, with inflows reaching US\$105.74 billion in 2010 - the highest level in China's inward FDI history. A serious commitment by the Chinese Government to further liberalise its FDI regime in accordance with its WTO commitments and to address the shortcomings outlined above will compound these positive factors and enable China to remain one of the top FDI destinations in the world in the decades ahead. 


\section{Bibliography}

Kearney, A.T. 2007, 2005 Foreign Direct Investment Confidence Index, A.T. Kearney, Chicago, Ill., viewed 18 April 2011, <http://www.atkearney.com/images/global/pdf/FDICI_2005. $\operatorname{pdf}>$

Kearney, A.T. 2010, 2010 Foreign Direct Investment Confidence Index, A.T. Kearney, Chicago, Ill., viewed 18 April 2011, <http://www.atkearney.com/index.php/Publications/ foreign-direct-investment-confidence-index.html>

State Council 2010, State Council's Regulations on Further Improvement on the Work of Utilising Foreign Direct Investment, [in Chinese], 13 April 2010, State Council, Beijing, viewed 18 April 2011, <http://www.gov.cn/zwgk/2010-04/13/content_1579732.htm>

Wang, R. (ed.) 1997, Report on Foreign Direct Investment in China: Industrial distribution of foreign direct investment, Economic and Management Press, Beijing.

\section{Endnotes}

1. Law of the People's Republic of China on Foreign-Capital Enterprises, Revised 31 October 2000, viewed 18 April 2011, <http://www.fdi.gov.cn/pub/FDI_EN/Laws/law_en_info.jsp?docid=51034>; Law of the People's Republic of China on Chinese-Foreign Contractual Joint Ventures, Revised 31 October 2000, viewed 18 April 2011, <http://www.fdi.gov.cn/pub/FDI_EN/Laws/law_en_info.jsp?docid=51032>; Law of the People's Republic of China on Chinese-Foreign Equity Joint Ventures, Revised 15 March 2001, viewed 18 April 2011, $<$ http://www.fdi.gov.cn/pub/FDI_EN/Laws/law_en_info.jsp?docid=51033>

2. The Company Law of the People's Republic of China, Revised 27 October 2005, viewed 18 April 2011, <http:// www.fdi.gov.cn/pub/FDI_EN/Laws/law_en_info.jsp?docid=50878>

3. Interim Provisions on Mergers and Acquisitions of Domestic Enterprises by Foreign Investors, 7 March 2003, viewed 18 April 2011, <http://www.fdi.gov.cn/pub/FDI_EN/Laws/law_en_info.jsp?docid=51173>

4. Provisions on Mergers and Acquisitions of Domestic Enterprises by Foreign Investors, Revised 8 August 2006, viewed 18 April 2011, <http://www.fdi.gov.cn/pub/FDI_EN/Laws/law_en_info.jsp?docid=66925>

5. Anti-Monopoly Law of the People's Republic of China, 30 August 2007, viewed 18 April 2011, <http://www. fdi.gov.cn/pub/FDI_EN/Laws/law_en_info.jsp?docid=85714>

6. Provisions on M\&As of Domestic Enterprises by Foreign Investors, Revised 22 June 2009, viewed 18 April 2011, <http://www.fdi.gov.cn/pub/FDI_EN/Laws/law_en_info.jsp?docid=108906>

7. Provisions on Guiding the Orientation of Foreign Investment, 11 February 2002, viewed 18 April 2011, <http:// www.fdi.gov.cn/pub/FDI_EN/Laws/law_en_info.jsp?docid=51267>

8. Catalogue for the Guidance of Foreign Investment Industries, Amended 11 March 2002, viewed 18 April 2011, <http://www.fdi.gov.cn/pub/FDI_EN/Laws/law_en_info.jsp?docid=51272>

9. Catalogue for the Guidance of Foreign Investment Industries, Amended 30 November 2004, viewed 18 April 2011, <http://www.fdi.gov.cn/pub/FDI_EN/Laws/law_en_info.jsp?docid=87902>

10. Catalogue of Priority Industries for Foreign Investment in the Central-West Region, Amended 23 December 2008, viewed 18 April 2011, <http://www.fdi.gov.cn/pub/FDI_EN/Laws/law_en_info.jsp?docid=101064>

11. Catalogue of Encouraged Hi-Tech Products for Foreign Investment, 2 June 2003, viewed 18 April 2011, <http://www.fdi.gov.cn/pub/FDI_EN/Laws/law_en_info.jsp?docid=51273>

12. Catalogue of Encouraged Hi-Tech Products for Foreign Investment, Revised 31 December 2006, [in Chinese], viewed 18 April 2011, <http://www.bjmbc.gov.cn/web2/fcsArticleDetail.jsp?article_id=11723920890001> 
13. Catalogue for the Guidance of Foreign Investment Industries, Amended 31 October 2007, viewed 18 April 2011, <http://www.fdi.gov.cn/pub/FDI_EN/Laws/law_en_info.jsp?docid=87372>

14. Catalogue for the Guidance of Foreign Investment Industries (Amendment Draft for Consultation), April 2011, [in Chinese], viewed 18 April 2011, <http:/www.fdi.gov.cn:8080/pub/FDI/wzyj/zcfgyj/ P020110412321086714049.pdf>

15. Enterprise Income Tax Law of the People's Republic of China, 16 March 2007, viewed 18 April 2011, <http:// www.fdi.gov.cn/pub/FDI_EN/Laws/law_en_info.jsp?docid=76240>

16. According to the 2010 Foreign Direct Investment Confidence Index (A.T. Kearney 2010), China remains the top-ranked destination by foreign investors - a title it has held since 2002.

17. Notice on Unification of City Maintenance and Construction Tax and Education Surcharge for Domestic Enterprises, Foreign Invested Enterprises, and Foreign Individuals, 18 October 2010, [in Chinese], viewed 18 April 2011, <http://www.chinatax.gov.cn/n8136506/n8136593/n8137537/n8138502/9938060.html> 